\title{
The staurosporine analog, Ro-31-8220, induces apoptosis independently of its ability to inhibit protein kinase C
}

\author{
Z Han $^{\star, 1}$, P Pantazis ${ }^{1}$, TS Lange ${ }^{1}$, JH Wyche ${ }^{1}$ and \\ EA Hendrickson ${ }^{1}$ \\ 1 Department of Molecular Biology, Cell Biology and Biochemistry, Box G-J1, \\ Brown University, Providence, RI 02912, USA \\ * Corresponding author: Z. Han, Department of Molecular Biology, Cell Biology \\ and Biochemistry, Brown University, Providence, RI 02912, USA; Tel: 401- \\ 863-9648, Fax: 401-863-2421; E-mail: zhiyong_han@brown.edu
}

Received 26.10.99; revised 19.1.00; accepted 15.2.00

Edited by CJ Thiele

\section{Abstract}

A series of bisindolylmaleimide (Bis) compounds were designed as analogs of the natural compound staurosporine (STS), which is a potent inducer of apoptosis. Many of the Bis analogs appear to be highly selective inhibitors of the protein kinase C (PKC) family, including PKC $-\alpha,-\beta,-\gamma,-\delta,-\varepsilon$, and $-\zeta$, unlike STS, which is an inhibitor of a broad spectrum of protein kinases. In this report we describe the effects of the Bis analogs, Bis-I, Bis-II, Bis-III and Ro-31-8220 on the survival and proliferation of $\mathrm{HL}-60$ cells, which have been widely used as a model cell system for studying the biological roles of PKC. Treatment of HL-60 cells with Bis-I, Bis-II, Bis-III, or Ro-31-8220 blocked phosphorylation of the PKC target protein Raf-1 with equal potency but did not appear to affect the general phosphorylation of proteins by other kinases. However, the biological effects of the Bis compounds were different: Bis-I and Bis-II had no observable effects on either cell survival or proliferation; Bis-IIl inhibited cell proliferation but not survival, whereas Ro-31-8220 induced apoptosis. These results indicated that the members of the PKC family which could be inhibited by the Bis analogs were required neither for survival nor proliferation of HL-60 cells. Analyses of cells treated with Ro-31-8220 showed that the apoptotic effect of Ro$31-8220$ on HL-60 cells was mediated by a well-characterized transduction process of apoptotic signals: i.e., mitochondrial cytochrome $c$ efflux and the activation of caspase- 3 in the cytosol. Moreover, the ability of Ro-31-8220 to induce apoptotic activation was completely inhibited by the overexpression of the apoptotic suppressor gene, Bcl-2, in the cells. Interestingly, proliferation of the Bcl-2-over-expressing cells was still sensitive to the presence of Ro-31-8220, suggesting that the inhibitory effects of Ro-31-8220 on viability and cell proliferation were mediated by different mechanisms. In particular, the apoptotic effect of Ro-31-8220 on cells was not altered by the presence of an excess amount of the other Bis analogs, suggesting that this effect is mediated by a factor(s) other than PKC or by a mechanism which was not saturable by the other Bis analogs. Finally, structure-function analyses of compounds related to Ro-31-8220 revealed that a thioamidine prosthetic group in Ro-311-8220 was largely responsible for its apoptotic activity. Cell Death and Differentiation (2000) 7, 521-530.

Keywords: apoptosis; PKC; analogs; staurosporine

Abbreviations: Bis, bisinodolylmaleimide; PMA, phorbol-12myristate acetate; STS, staurosporine; CaM kinase, calmodulindependent kinase; PKA, protein kinase A; PKG, protein kinase G

\section{Introduction}

Apoptosis is an essential mechanism for the development of all mammalian organisms. ${ }^{1}$ Recent studies indicate that the fundamental apoptotic machinery, which consists of various effectors and suppressors, is conserved throughout evolution. $^{2-4}$ The key apoptotic effectors appear to be a family of aspartate-specific proteases called caspases. ${ }^{5-7}$ Caspases exist as inactive proenzymes in healthy cells and are then activated by proteolysis in apoptotic cells. Once activated, caspase cleave a set of cellular substrates, ${ }^{8}$ which ultimately result in cell death. The key apoptotic suppressors appear to be members of the $\mathrm{Bcl}-2$ gene family, which regulate apoptosis at the level of cytochrome $c$ efflux from the mitochondria ${ }^{9}$ and/or caspase activation. ${ }^{10}$ The compound staurosporine (STS), which was originally isolated from Streptomyces as a potential anti-fungal agent, has achieved certain notoriety due to its ability to potently induce apoptosis in virtually all mammalian cells. However, the mechanism by which STS causes apoptosis is still poorly understood. One plausible hypothesis has been that STS's effect is mediated through protein kinase $\mathrm{C}(\mathrm{PKC})$, given the fact that STS has also been shown to be a potent inhibitor of PKC. This hypothesis was relatively attractive since numerous studies had demonstrated that the inhibition of PKC by a variety of pharmacological agents correlated with apoptotic induction in many cell types. ${ }^{11-19}$ In addition, it has been demonstrated that PKC $\partial$ is cleaved by caspase- 3 in human monocytic leukemia U937 cells during apoptotic induction by etoposide, cisplatinum or Ara-C, ${ }^{20}$ suggesting that inhibition of this enzyme is an important aspect of apoptosis. Consistent with these observations, it has also been suggested that the phosphorylation of the apoptotic suppressor, Bcl-2, by mitochondrial PKC $\alpha$ is required for its ability to inhibit apoptosis. $^{21}$

Unfortunately, in order for STS to induce apoptosis it is often used in a concentration range of 1 to $5 \mu \mathrm{M}$, which is a concentration at which it acts as a rather non-specific inhibitor of a variety of kinases including, in addition to $P K C$, protein kinase $A(P K A)$, protein kinase $G(P K G)$, 
myosin light-chain kinase, calmodulin-dependent kinase (CaM kinase), and the p60 v-Src protein tyrosine kinase. $^{22,23}$ Therefore, even though apoptosis induction in various cell types has been associated with PKC inhibition, a functional connection between PKC inhibition by STS and apoptosis remains unproven. ${ }^{24,25}$

To complicate matters, a positive regulatory role in apoptotic induction for various members of the PKC family (of which there are at least 11 members $^{26}$ has been postulated. For example, it was recently reported that (i) PKC $\delta$ activity was essential for etoposideinduced apoptosis in salivary gland acinar cells; ${ }^{27}$ and (ii) over-expression of PKC $\alpha$ in the prostate epithelial tumor cell line, LNCaP, resulted in apoptosis. ${ }^{28}$ Furthermore, it has been demonstrated that PKC $\alpha$ and $\delta$ are activated by a caspase-dependent mechanism during apoptosis induction in human promyelocytic leukemia HL-60 cells by 7-hydroxystaurosporine, camptothecin, or etoposide ${ }^{29}$ and by UV irradiation in normal human dermal keratinocytes, ${ }^{30}$ respectively. Thus, both the activation and inhibition of PKC isoforms have been correlated with apoptosis and the precise role of this important family of protein kinases in cell survival remains controversial.

In recent years, a class of bisindolylmaleimide (Bis) analogs, modeled on the polyaromatic aglycon portion of the STS molecule, were synthesized and found to be highly selective inhibitors of multiple PKC isoenzymes, including at least PKC- $\alpha,-\beta,-\gamma,-\delta,-\varepsilon$, and $-\zeta^{31-35}$ Impressively, when given orally to experimental rats, one analog, Ro-320432, prevented T-cell-driven induction of host versus graft responses and secondary paw swelling in adjuvant-induced arthritis. ${ }^{36}$ These findings suggested that the Bis compounds might be useful as drugs to treat inflammatory and autoimmune diseases which are linked to apoptosis. In addition, the high selectivity of the Bis analogs of STS towards PKC as opposed to other protein kinases also suggested that these analogs might be useful tools for probing the various biological roles of PKC including apoptosis regulation.

To investigate whether the selective inhibition of PKC in cancer cells by the Bis analogs of STS results in inhibition of cell proliferation, induction of cell differentiation, or apoptosis we tested the effect of these compounds on HL-60 human promyelocytic leukemia cells, which have been used as a model cell system for studying PKC. In this report, we demonstrate that the Bis analogs Bis-I, Bis-II, Bis-III, and Ro-31-8220 had different effects on proliferation and survival of HL-60 cells, although they inhibited PKC activity equally well. Specifically, Bis-I, Bis-II, and Bis-III had cytostatic effects whereas Ro-31-8220 potently induced apoptosis. Additional results strongly suggested that the apoptotic activity of Ro-31-8220 was due to the presence of a unique prosthetic group in this compound and that its apoptotic effect on cells was not altered by the presence of other Bis analogs. These results demonstrate that apoptotic induction in HL-60 cells proceeds in a PKC-independent fashion and they shed light on the mechanism by which STS induces cell death.

\section{Results}

\section{The effects of bisindolylmaleimide analogs on protein phosphorylation and cell proliferation}

The STS bisindolylmaleimide analogs Bis-I, Bis-II, Bis-III, and Ro-31-8220 (Figure 1) are equipotent and highly selective inhibitors of PKC in in vitro kinase assays. ${ }^{32}$ In contrast, Bis-V (Figure 1) does not inhibit PKC nor several other protein kinases. ${ }^{33}$ Therefore, we tested these compounds for their effects on the phosphorylation of proteins in, and the proliferation of, HL-60 cells in vivo. Treatment of HL-60 cells with $100 \mathrm{nM}$ phorbol-12-myristate acetate (PMA) caused the hyperphosphorylation of c-Raf-1 a known PKC family target ${ }^{37}$ (Figure 2A, compare lanes '-' and '+'). However, pretreatment of the cells with $10 \mu \mathrm{M}$ Bis-I, Bis-II, Bis-III, or Ro-318220 , but not Bis- $\mathrm{V}$, completely blocked this phosphorylation (Figure 2A). In contrast, none of these compounds showed significant inhibitory effect on the general phosphorylation of proteins in HL-60 cells stimulated by serum (Figure $2 \mathrm{~B}$ ). Thus, these results confirmed the in vitro data obtained by Davis et al. $^{32,33}$ that Bis-I, Bis-II, Bis-III, and Ro-31-8220 were relatively selective and potent inhibitors of PKC.

\section{Induction of apoptosis by Ro-31-8220}

Next, the biological effects of these compounds on HL-60 cells were investigated. Treatment of HL-60 cells with $10 \mu \mathrm{M}$ Ro31-8220, but not the other Bis compounds, for $24 \mathrm{~h}$ induced apoptosis. DAPI staining of the cells at the end of the treatment showed that Ro-31-8220 induced formation of densely stained granular nuclear bodies, which are a classic hallmark of apoptosis, ${ }^{38}$ in almost all the cells (Figure 3 ). In contrast, the percentage of apoptotic cells caused by treatment with the other compounds remained at the basal level, approximately $1-5 \%$. Biochemical analyses showed that Ro-31-8220, but not other compounds, also induced (i) the cleavage of Numa (Figure 4A), a nuclear target of caspases during apoptosis; ${ }^{39}$ and (ii) the internucleosomal degradation of chromatin DNA into nucleosomal fragments (Figure 4B), another hallmark of apoptosis. ${ }^{40}$ In addition, treatment of HL-60 cells with Ro-318220 rapidly induced the efflux of mitochondrial cytochrome $\mathrm{c}$ into the cytosol, which was followed by the activation of caspase-3 but not caspase-2 (Figure 5A). In contrast, Bis-I, Bis-II, Bis-III, and Bis-V failed to induce these biochemical changes (Figure 5B). Therefore, the apoptotic effect of Ro-318220 on HL-60 cells appeared to be mediated by a wellcharacterized transduction process of apoptotic signals, i.e., mitochondrial cytochrome c efflux, and activation of caspase-3 in the cell cytosol. Prolonged treatment of HL-60 cells with $10 \mu \mathrm{M}$ of Bis-I, Bis-II, Bis-III, or Bis-V for up to 4 days failed to induce apoptosis. Interestingly, Bis-I, Bis-II, and Bis-V did not have observable effects on cell proliferation, whereas Bis-III profoundly inhibited proliferation in cell growth assays (Figure $6)$. Taken together, these results indicated that although Bis-I, Bis-II, Bis-III, and Ro-31-8220 were equally potent PKC inhibitors (Figure $2 \mathrm{~A}$ ) ${ }^{32,33}$ the effects of these compounds on cell survival and growth were very different. More importantly, these experiments clearly demonstrated that the inhibition of PKC was a separable, distinct and unrelated event from apoptotic induction and cell proliferation. 


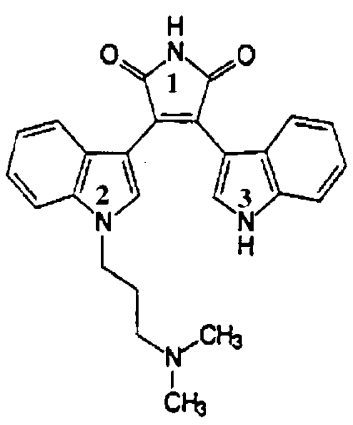

Bis-I<smiles>CN1C(=O)C(C2=C(c3c[nH]c4ccccc34)C(=O)N2C)=C(c2c[nH]c3ccccc23)C1=O</smiles>

Bis-V<smiles>CN1CCCC1CCn1cc(C2=C(c3c[nH]c4ccccc34)C(=O)NC2=O)c2ccccc21</smiles>

Bis-II

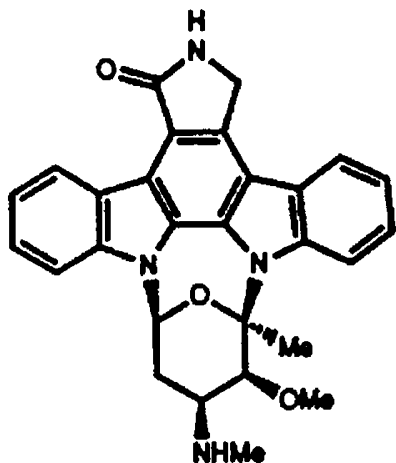

Staurosporine<smiles>NCCCn1cc(C2=C(c3c[nH]c4ccccc34)C(=O)NC2=O)c2ccccc21</smiles>

Bis-III<smiles>Cn1cc(C2=C(c3cn(CCCSC(=N)N)c4ccccc34)C(=O)NC2=O)c2ccccc21</smiles>

Ro-31-8220

Figure 1 Structures of the Bis analogs. For description of the synthesis of the analogs, see references by Davis et al. ${ }^{32,33}$ For convenience, the three nitrogen atoms in the compounds are denoted as 1,2 , and 3 . For IC50 or $\mathrm{K}_{\mathrm{i}}$ values of the Bis compounds, see reports by Davis et al. ${ }^{32,33}$ and Wilkinson et al. ${ }^{35}$

The structural similarities amongst the Bis analogs suggested that they might interact with the same cellular target protein(s) regardless of their ability to induce apoptosis. If this were true, then the non-apoptotic Bis analogs might compete with the apoptotic Ro-31-8220 compound for binding to the same target protein(s) and, therefore, partially or completely, inhibit the ability of Ro-318220 to induce apoptosis through this protein(s). To experimentally test this hypothesis, HL-60 cells were pretreated with $20 \mu \mathrm{M}$ of Bis-I, Bis-II, Bis-III, Bis-IV, or Bis-V for 60 min and then $10 \mu \mathrm{M}$ of Ro-31-8220 was added to the cell cultures and incubation continued for $20 \mathrm{~h}$. The ability of Ro-31-8220 to induce apoptosis was not affected by the presence of any of the Bis analogs (data not shown), suggesting that it interacts with a unique cellular target(s).

\section{Structural changes in Ro-31-8220 alters its apoptotic-inducing capability}

The alteration of the $\mathrm{N}-1$ prosthetic group in Bis $\mathrm{V}$ (Figure 1) correlated with the lack of its inhibitory effect on PKC. ${ }^{32,33}$ In addition, the presence of widely disparate prosthetic groups at the $\mathrm{N}-2$ nitrogen seemed not to affect the ability of these compounds to inhibitPKC (Figure 1). Therefore, it seemed likely that the PKC inhibitory activity of the Bis analogs was largely associated with the basic polyaromatic aglycon portion of their structures and not with their respective constituent prosthetic groups. However, it was possiblethat the prosthetic group of Ro31-8220 was responsible for its apoptosis-inducing activity. If this were true, then substitution of this prosthetic group with a different moiety, such as the one in Ro-31-7549 or Ro-31-8425 (Figure 7), should alter its apoptosis-inducing activity. Indeed, Ro-31-7549 and Ro-31-8425 were significantly less active than Ro-31-8220 in inducing apoptosis (Figure 7). Therefore, the presence of the thioamidine prosthetic group at the $\mathrm{N}-2$ position of Ro-31-8220 was responsible for its potent apoptotic activity. It should also be noted that Bis-III is a N-3 de-methylated form of Ro-31-7549 (Figure 7). Thus, in contrast to Ro-31-7549 which showed some apoptotic activity, the complete lack of apoptotic activity of Bis-III indicated that the N-3 methyl group was also important for the apoptotic activity of Ro-31-7549.

\section{Overexpression of $\mathrm{Bcl}-2$ blocks induction of apoptosis, but not inhibition of cell proliferation, by Ro-31-8220}

Overexpression of the apoptosis suppressor, Bcl-2 in different cell types blocks the chemical induction of apoptosis, but not necrosis. ${ }^{10,41}$ Therefore, the specific apoptosis-inducing activity of a chemical can be best demonstrated by the resistance of cells overexpressing an apoptosis suppressor to the apoptotic effect of the chemical. To experimentally test if the transduction pathway for the apoptotic signals of Ro-318220 was inhibitable by $\mathrm{Bcl}-2$, transgenic $\mathrm{Bcl}-2: \mathrm{HL}-60$ cells 


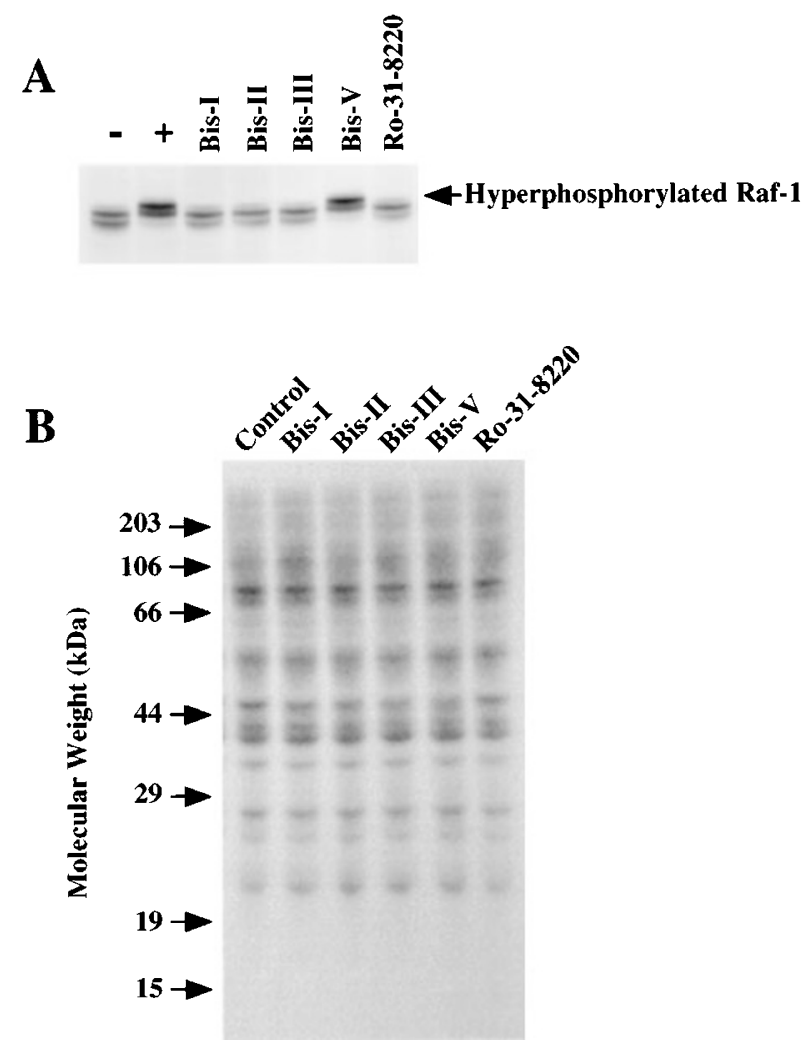

Figure 2 Effects of the Bis compounds on protein phosphorylation. (A) Bis compounds inhibit the phosphorylation of Raf- 1 by PKC. HL-60 cells were left untreated or treated with $10 \mu \mathrm{M}$ of the indicated compound for $1 \mathrm{~h}$. Then, the cells were left unstimulated $(-)$ or stimulated with $100 \mathrm{nM} \mathrm{PMA} \mathrm{(+)} \mathrm{for} 30 \mathrm{~min}$ The status of Raf phosphorylation was then determined by Western blot analysis. (B) Lack of inhibitory effect of Bis compounds on the general phosphorylation of cellular proteins. HL-60 cells arrested in serum-free medium were metabolically radiolabeled with ${ }^{32} \mathrm{P}$-phosphoric acid (see Materials and Methods). The cells were then either left untreated (Control) or treated with $10 \mu \mathrm{M}$ of the indicated compound for $1 \mathrm{~h}$. The cells were then stimulated with $10 \%$ fetal bovine serum for $10 \mathrm{~min}$. Incorporation of $\left.{ }^{32} \mathrm{P}\right]$ into proteins was subsequently analyzed by electrophoresis and autoradiography

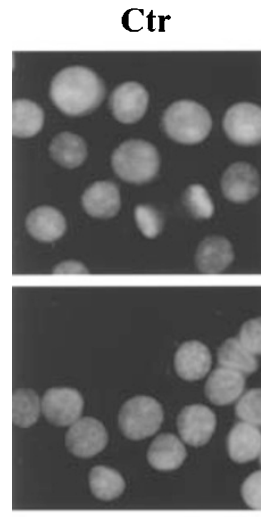

Bis-III

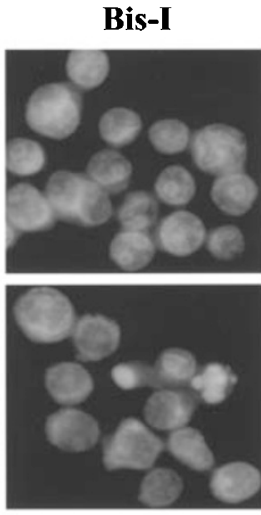

Bis-V
Bis-II

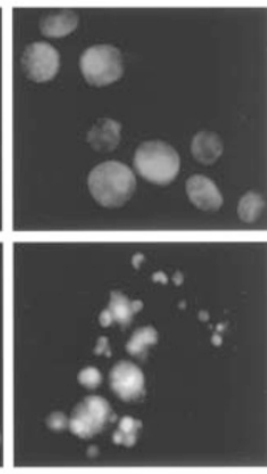

Ro-31-8220
Figure 3 Induction of nuclear apoptotic bodies by Ro-31-8220. HL-60 cells were left untreated (Control) or treated with $10 \mu \mathrm{M}$ of the indicated compound for $24 \mathrm{~h}$. The cells were then fixed, stained with DAPI, and photographed under a fluorescent microscope
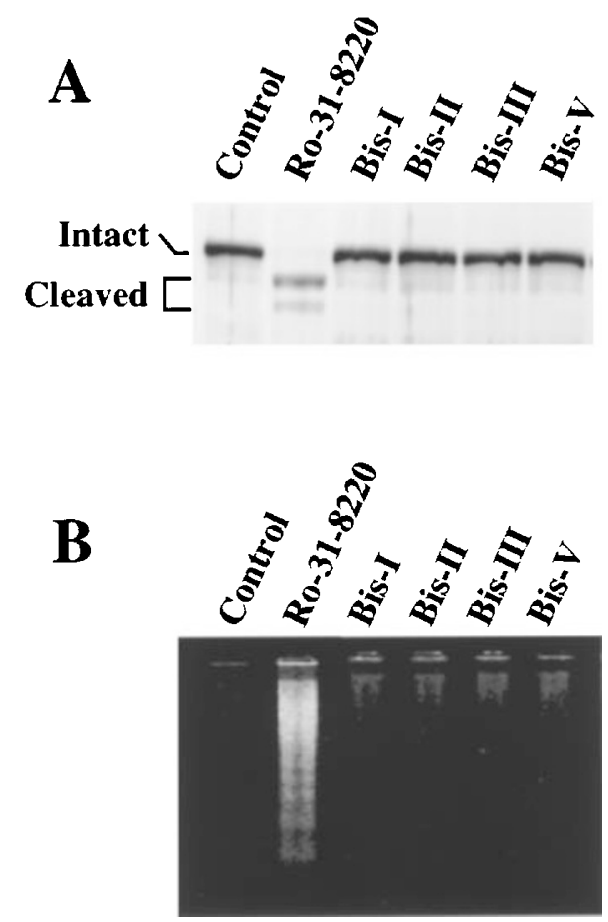

Figure 4 Induction of apoptosis by Ro-31-8220. HL-60 cells were left untreated (Control) or treated for $24 \mathrm{~h}$ with $10 \mu \mathrm{M}$ of the indicated compound. At the end of the treatment, whole cell extract and DNA samples were prepared for (A) Western blot (WB) analysis of Numa cleavage, and (B) agarose gel electrophoresis analysis of DNA fragmentation, respectively

that overexpress Bcl-2 $2^{42,43}$ were treated with $10 \mu \mathrm{M}$ of Ro-318220 for up to 24,48 and $72 \mathrm{~h}$ and then examined for visible features of apoptosis. Microscopic examination of DAPIstained cells showed that only a small fraction $(<10 \%)$ of the $\mathrm{Bcl}-2: \mathrm{HL}-60$ cells treated with $10 \mu \mathrm{M}$ of Ro-31-8220 for up to $72 \mathrm{~h}$ exhibited typical nuclear apoptotic bodies (Figure 8A). In addition, biochemical analysis showed that treatment of Bcl2:HL-60 cells with Ro-31-8220 did not result in detectable mitochondrial cytochrome $c$ efflux into the cytosol, activation of caspase-3, degradation of Numa, nor degradation of DNA (Figure 8C,D). These results indicated that over-expression of Bcl-2 in HL-60 cells essentially blocked the apoptotic effect of Ro-31-8220. In striking contrast, however, the proliferation of $\mathrm{Bcl}-2: \mathrm{HL}-60$ cells remained very sensitive to the presence of Ro-31-8220 (Figure 8B) and appeared to arrest predominately at the G2/M phase of the cell cycle (data not shown). Therefore, over-expression of $\mathrm{Bcl}-2$ blocked the apoptotic effect of Ro-31-8220, whereas it failed to prevent its inhibitory effect on cell proliferation.

\section{Discussion}

In this study, we have attempted to dissect out the role that PKC enzymes inhibitable by the Bis family compounds play in cellular growth and survival. Experimentally, we took advantage of the STS analogs Bis-I, Bis-II, Bis-III and Ro31-8220, which are synthetic and equally potent PKC inhibitors, but which had different effects on the proliferation and survival of $\mathrm{HL}-60$ cells. More specifically, treatment of the 
A

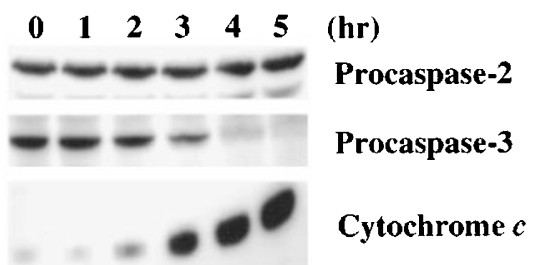

B

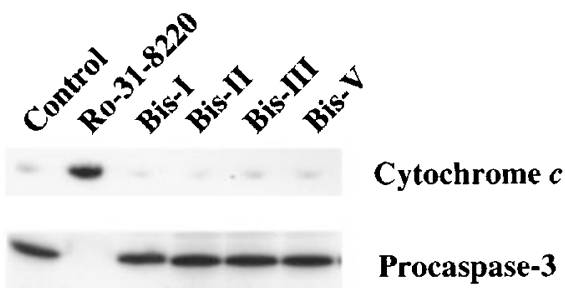

Figure 5 Rapid induction of mitochondrial cytochrome $c$ efflux and caspase-3 activation by Ro-31-8220. (A) HL-60 cells were treated with $10 \mu \mathrm{M}$ of Ro-31-8220 for $0,1,2,3,4$ and $5 \mathrm{~h}$. At the end of each treatment, S-100 extract was prepared from the cells, and aliquots were subjected to SDS-PAGE and Western blot analysis to determine the status of caspase activation and the accumulation of cytochrome $c$ in the cytosol. The reduction in the level of procaspase- 3 indicates the activation of caspase- 3 and the accumulation of cytochrome $c$ in the S-100 indicates mitochondrial cytochrome $c$ efflux. (B) Selective induction of mitochondrial cytochrome $c$ efflux and caspase-3 activation by Ro-31-8220. HL-60 cells were left untreated (Control) or were treated with $10 \mu \mathrm{M}$ of the indicated compound for $5 \mathrm{~h}$. S-100 extract was then prepared from the cells and analyzed for the status of procaspase-3 and cytochrome $c$

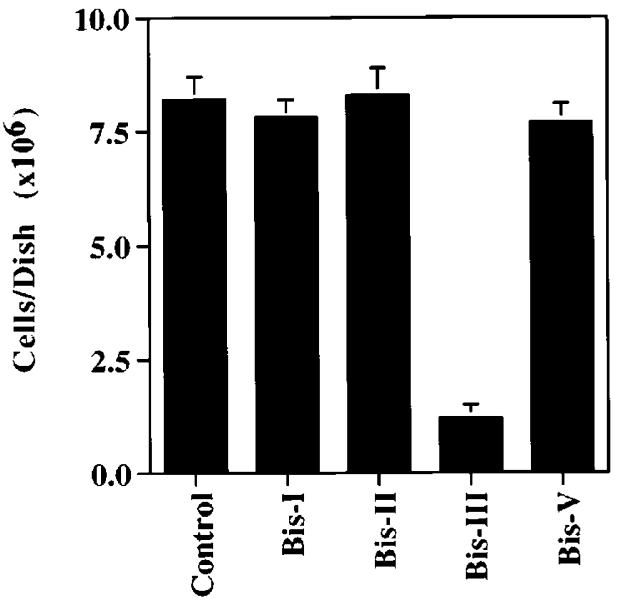

Figure 6 Effects of the Bis compounds on cell proliferation. HL-60 cells were left untreated (Control) or treated with $10 \mu \mathrm{M}$ of the indicated compound for 4 days. Cell numbers in triplicate cultures were determined at the end of the treatment. The data presented here represent the result from a typical experiment. The assay was repeated twice

cells with Bis-I and Bis-II at concentrations that completely blocked PKC activity had no effect on either cell proliferation or survival. These results strongly suggested that members of the PKC family which are regulated by Bis compounds are not absolutely required for either of these cellular functions and, by extension, implied that these PKC isoforms are not the critical targets of STS. The STS analog, Ro-31-8220, however, induced apoptosis of HL-60 cells as well as the parental compound. Additional studies suggested that the apoptotic activity of Ro-31-8220 was due to the presence of a unique prosthetic group which enabled the compound to activate apoptosis via a mechanism which was PKCindependent, but suppressible by $\mathrm{Bcl}-2$.

\section{Induction of apoptosis by STS}

All mammalian cells appear capable of carrying out apoptosis when provoked by the appropriate environmental cues. ${ }^{2,4}$ Productive responses to apoptotic signals, however, appear to be quite cell-type specific. For example, low levels of ionizing radiation, to which most fibroblastic cells are refractory, potently induces apoptosis in lymphoid precursor cells. ${ }^{44,45}$ Similarly, the withdrawal of growth factors drives most cells into quiescence, but causes hematopoietic cell lineages to undergo rapid apoptosis. ${ }^{46}$ STS, is relatively unique in its ability to rapidly and completely drive virtually all mammalian cell lines into apoptosis..$^{23,47,48}$ Since STS is a nonselective inhibitor of a diverse array of protein kinases, ${ }^{22,23}$ it is likely that the inhibition of one or more of these kinases is directly responsible for STS's apoptotic activity. In this study, we demonstrated that Bis-I and Bis-II had no effects on either proliferation or survival of $\mathrm{HL}-60$ cells (Figures 2, 3, and 4). Others have demonstrated that Bis compounds including Bis-I are potent inhibitors of the PKC isozymes, PKC $-\alpha,-\beta,-\gamma,-\delta,-\varepsilon$, and $-\zeta$, which are the same PKC isozymes inhibitable by STS. ${ }^{31,34}$ These results, taken together, clearly demonstrate that the PKC inhibitory activity of STS can be separated from its ability to induce apoptosis and thus imply that PKC is not the relevant downstream kinase for STS-induced apoptosis. In addition, our experiments rule out the oncogenic kinase, Raf-1, as the downstream kinase. Thus, complete inhibition of Raf-1 phosphorylation - and therefore its activation - by the STS analogs, Bis-I, Bis-II and Bis-III did not induce HL-60 cells to undergo apoptosis (Figures 2, 3 and 4). Therefore, while the experiments described here cannot delineate which kinase(s) is targeted by STS, our results unequivocally rule out multiple PKC isozymes and Raf-1 as being that kinase. In a broader sense, the identification of the kinase targeted by STS begs the larger question of what are the relevant biological targets related to apoptosis of that kinase. The ultimate identification of the protein(s) affected by STS treatment is important since that protein(s) would be an extremely attractive target for chemotherapeutic intervention in malignant cells. The use of Ro-31-8220 or its derivatives may permit the identification of the target(s).

\section{The roles of PKC in proliferation and survival of HL-60 cells}

It has long been established that the activation of PKC in HL60 , as well as in other monocytic leukemia cell lines, leads to the differentiation of these cells into monocytes/macrophages. ${ }^{49}$ This PKC-mediated cell differentiation process is inhibitable by PKC inhibitors. Indeed, we observed that all of the Bis compounds that were capable of inhibiting PKC blocked differentiation of $\mathrm{HL}-60$ cells into monocytes following induction by the potent PKC activator, PMA (data not shown). However, the issue of whether or not PKC also played roles in 
<smiles>NCCCn1cc(C2=C(c3c[nH]c4ccccc34)C(=O)NC2=O)c2ccccc21</smiles>

Bis-III<smiles>Cn1cc(C2=C(c3cn(CCCN)c4ccccc34)C(=O)NC2=O)c2ccccc21</smiles>

Ro-31-7549<smiles>Cn1cc(C2=C(c3cn(CCCSC(=N)N)c4ccccc34)C(=O)NC2=O)c2ccccc21</smiles>

Ro-31-8220<smiles>Cn1cc(C2=C(c3c4n(c5ccccc35)CCC(CN)C4)C(=O)NC2=O)c2ccccc21</smiles>

Ro-31-8425

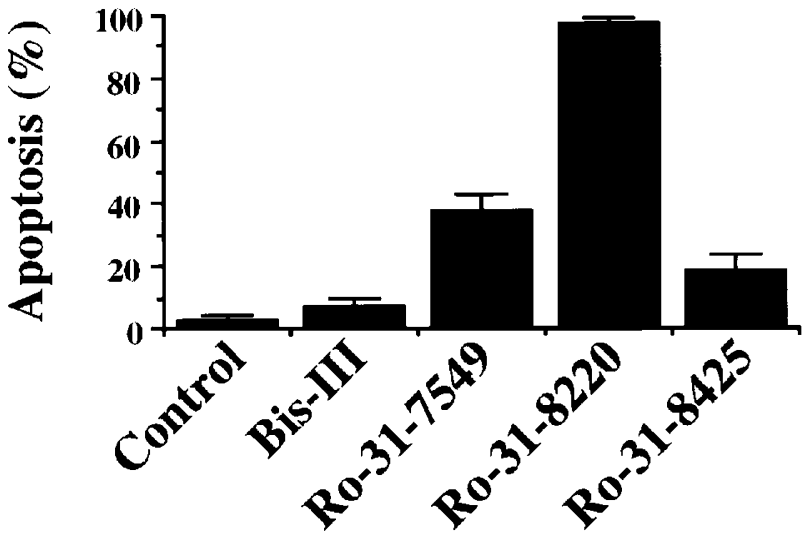

Figure 7 Structure-function analyses of Ro-31-8220 related compounds. For convenience, the three nitrogen atoms in the compounds are denoted as 1,2 and 3 . $\mathrm{HL}-60$ cells were left untreated or treated with $10 \mu \mathrm{M}$ of each compound for $24 \mathrm{~h}$. The cells were then fixed, stained with DAPI, and the percentage of cells with apoptotic nuclear bodies was quantified. The average of two experiments is presented here

the proliferation and survival of HL-60 and other monocytic leukemia cells was much less clear, though numerous studies had suggested that this was likely to be the case. ${ }^{19}$ Using the STS analogs, Bis-I, Bis-II, Bis-III, and Ro-31-8220, however, we were able to demonstrate that $\mathrm{PKC}$ is required neither for proliferation nor for cell survival in the HL-60 cell system. Thus, although Bis-I, Bis-II, Bis-III, and Ro-31-8220 were equipotent in their ability to inhibit PKC activity in HL-60 cells (Figure 2), Bis-I and Bis-II did not effect proliferation and survival of HL-60 cells while Bis-III and Ro-31-8220 inhibited the proliferation (Figures 4 and 6 ) and only Ro-31-8220 induced apoptosis of HL-60 cells (Figures 3 and 4). Bis-V, which does not inhibit PKC, ${ }^{32,33}$ lacked any effect on the proliferation and survival of HL-60 cells (Figures 3, 4 and 6) and did not block PMA-induced monocytic differentiation (data not shown). Thus, these experiments strongly suggest that while PKC is required for cellular differentiation it is not essential for either proliferation or survival. Similar to our study, Wang et al. using a different STS analog, 7hydroxystaurosporine (UCN-01), demonstrated that the inhibition of PKC by UCN-01 was not correlated with UCN01 's ability to induce apoptosis. ${ }^{50}$ These authors suggested instead that the ability of UCN-01 to activate the histone $\mathrm{H} 1$ kinase activities of cdk-1 and cdk-2 might be casually related to the induction of apoptosis by UCN-01. ${ }^{50}$ Therefore, it is also possible that the simultaneous inhibition of PKC and the activation of other target(s) such as cdk-1 or cdk-2 underlie the mechanism by which Ro-31-8220 induces apoptosis. However, this hypothesis remains to be investigated.

\section{Induction of apoptosis by Ro-31-8220}

Activation of the Jun $\mathrm{N}$-terminal kinase (JNK) has been correlated with apoptosis induction by a diverse group of chemicals. ${ }^{51-56}$ Further, it was demonstrated that treatment of Rat-1 fibroblast cells with Ro-31-8220 quickly induced JNK activation. ${ }^{57}$ However, treatment of rat mesangial cells for a long period with Ro-31-8220 alone did not induce JNK activation, although this could be attenuated by tumor necrosis factor $\alpha$ (TNF). ${ }^{54}$ Thus, although the treatment of the rat mesangial cells with Ro-31-8220 or TNF alone had no significant effect on the cell viability, co-treatment of the cells with Ro-31-8220 and TNF induced apoptosis in the majority of the cells within a period of $4-6 \mathrm{~h} .{ }^{54}$ It was then suggested that sustained JNK activation in the cells in the presence of Ro-318220 was required for apoptosis induction by TNF- $\alpha{ }^{54}$. In contrast to these studies, however, we detected no apparent changes in JNK activity in HL-60 cells during the apoptosis induction process by Ro-31-8220 as confirmed by JNK activity assays and Western blot analyses for the identification of activated (or phosphorylated) JNK (data not shown). We did detect a significant increase in JNK activity only in cells that had progressed to the end of the apoptosis process, i.e., after caspase-3 activation, degradation of caspase-3 target 
A

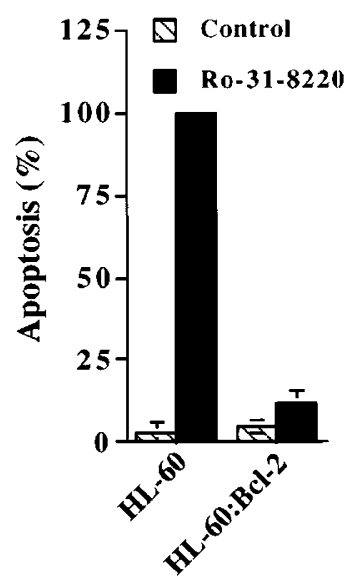

C

-+ Ro-31-8220

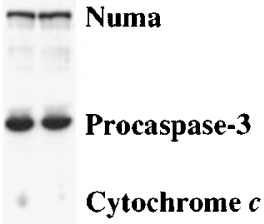

B

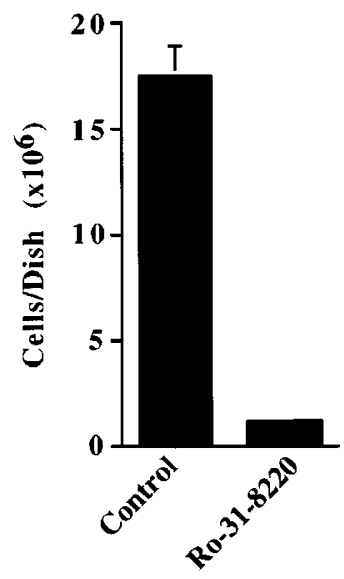

D

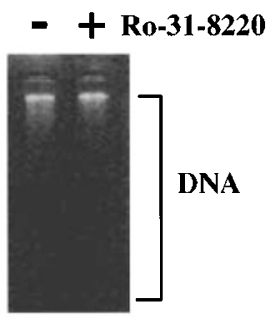

Figure 8 Overexpression of $\mathrm{Bcl}-2$ in $\mathrm{HL}-60$ cells blocks the apoptotic, but not the anti-proliferative, effect of Ro-31-8220. (A) Bcl-2 inhibits apoptosis induction by Ro-31-8220. DAPI staining analysis of apoptosis in HL-60 and Bcl-2:HL-60 cells cultured in medium in the absence or presence of $10 \mu \mathrm{M}$ Ro-31-8220 for $72 \mathrm{~h}$. (B) Ro-31-8220 inhibits proliferation of $\mathrm{Bcl}-2: \mathrm{HL}-60$ cells. HL-60 cells were cultured in the absence or presence of $10 \mu \mathrm{M}$ Ro-31-8220 for 6 days. Cell numbers were then determined in triplicate. This figure represents the result from a typical experiment. (C) HL-60 cells were left untreated $(-)$ or treated $(+)$ with $10 \mu \mathrm{M}$ Ro-31-8220 for $24 \mathrm{~h}$. Whole cell or S-100 extracts were then prepared from the cells and used for the analysis of Numa cleavage, procaspase- 3 activation and mitochondrial cytochrome c efflux. (D) Lack of DNA degradation in Ro-318220-treated Bcl-2:HL-60 cells. Bcl-2:HL-60 cells were left untreated ( - ) or were treated $(+)$ for $24 \mathrm{~h}$ with $10 \mu \mathrm{M}$ of Ro-31-8220. DNA samples were then prepared from the cells and analyzed by agarose gel electrophoresis

proteins, and DNA degradation (data not shown). Therefore, it is unlikely that JNK activation is required for the transduction of the apoptotic signal caused by Ro-31-8220 in HL-60 cells.

Another cellular factor that has been proposed to mediate, directly or indirectly, the apoptotic effect of Ro$31-8220$ on glioblastoma cells is $p 53 .^{58}$ It was demonstrated that the treatment of two glioblastoma cell lines with Ro-31-8220 caused these cell lines to undergo apoptosis, which was preceded by the nuclear accumulation of wildtype $\mathrm{p53}$, a protein that has been shown to be required for apoptosis induction in certain cell types. ${ }^{41}$ However, since HL-60 cells are deficient in p53 expression due to large deletions in the gene, ${ }^{59}$ it is clear that the Ro-31-8220induced apoptosis in HL-60 cells occurred by a p53independent mechanism.

Lastly, it should be noted that Ro-31-8220 and other Bis analogs have been reported to block apoptosis induction in cerebellar granule cells following deprivation of depolarizing concentrations of $\mathrm{KCl}^{25}$ In addition, it has been demonstrated that Ro-31-8220 not only lacked an apoptotic effect on immature rat thymocytes, but blocked the apoptotic effect of thapsigargin. ${ }^{24}$ In contrast, our results show that Ro-31-8220 is a very potent inducer of apoptosis in HL-60 cells. These studies suggest that the apoptotic effect of Ro31-8220 may be cell-type specific and suggest that caution should be used in extrapolating these data directly to other cell lines and/or tissues.

\section{Ro-31-8220 is a model compound that can be used for the development of chemicals that modulate apoptosis and for the identification of cellular factors that regulate apoptosis}

Given the extensive structural similarities of the Bis analogs, we expected that some of these compounds would compete with Ro-31-8220 for binding to the same cellular apoptosis regulator(s) and thus partially or completely block the apoptotic effect of Ro-31-8220. However, pre-exposure of HL-60 cells to excess amounts of Bis-I, Bis-II, Bis-III, or Bis-V had no detectable effect on the apoptotic response of the cells to Ro31-8220. These results suggested that the apoptotic effect of Ro-31-8220 was mediated via a specific cellular factor(s) involved in apoptosis regulation, which did not interact with or was not regulated by the other Bis analogs. It can be envisioned that binding of Ro-31-8220 to this factor alters its activity, either positively or negatively, which then rapidly activates the apoptosis process. Therefore, identification of this putative Ro-31-8220 binding factor should provide information for the development of novel, specific inducers of apoptosis.

Our results showed that the $\mathrm{N}-2$ thioamidine prosthetic group is largely responsible for the potent apoptotic activity of Ro-31-8220, and substitution of this group with an amine group such as the one in Ro-31-7549 reduced its apoptotic activity (Figure 7). However, it is also interesting to note that both Ro-31-8220 and Ro-31-7549 contain an N-3 methyl prosthetic group, which is absent on the other non-apoptotic Bis analogs (Figures 1 and 7). For example, Bis-III is an N-3 de-methylated version of Ro-31-7549 (Figure 7), and Bis-III completely lacked apoptotic activity (Figures 3 and 7). Therefore, as far as the apoptotic activity of Ro-31-7549 is concerned, the presence of the N-3 methyl group is required. By extension, we predict that the presence of the N-3 methyl group will also be required for the apoptotic activity of Ro-318220 , and in its absence the apoptotic activity of Ro-31-8220 would probably be reduced. Therefore, the potent apoptotic activity of Ro-31-8220 is likely due to the presence of both the $\mathrm{N}-2$ thioamidine and N-3 methyl groups.

The chemical pathways for the synthesis of Bis analogs including Ro-31-8220 are known, ${ }^{32,33}$ and it is therefore possible to produce combinatorial libraries of Ro-31-8220 analogs with various modifications at the $\mathrm{N}-2$ and/or $\mathrm{N}-3$ positions in the maleimide ring. Further, the use of cell systems such as HL-60 and Bcl-2:HL-60 should make it possible to rapidly screen these combinatorial libraries. We envision that compounds which induce apoptosis of HL-60, but not Bcl-2:HL-60 cells can be quickly identified. Such compounds may have potential chemotherapeutic value. 


\section{Materials and Methods}

\section{Materials}

Fetal bovine serum (FBS), sodium fluoride, sodium orthovanadate, EDTA, phenylmethylsulfonyl fluoride (PMSF), aprotinin, antipain, and leupeptin, were purchased from Sigma Chemical Co. (St Louis, MO, USA). Mouse monoclonal caspase- 3 and c-Raf- 1 antibodies were purchased from Transduction Laboratories, Inc. (Lexington, KY, USA). Mouse monoclonal Numa antibodies were purchased from Oncogene Research Products, Inc. (Cambridge, MA, USA). ECL Western blot analysis reagents were from Amersham Life Science, Inc. (Arlington Heights, IL, USA). The compounds Ro-31-8220, Ro-31-7549, Ro-318425, Ro-32-0432, and bisindolemaleimide-I, -II, -III, -IV and -V (Bis-I, Bis-II, Bis-III, Bis-IV and Bis-V, respectively) were purchased from Calbiochem-Novabiochem, Inc. (Boston, MA, USA), dissolved in dimethyl sulfoxide at a $10 \mathrm{mM}$ concentration, and stored at $-20^{\circ} \mathrm{C}$. Under this storage condition, the biological activities of these compounds are very stable. $\mathrm{HCl}$-free $\left[{ }^{32} \mathrm{P}\right]$ phosphoric acid was obtained from ICN Pharmaceuticals, Inc. (Irvine, CA, USA).

\section{Cells stocks}

$\mathrm{HL}-60$ and $\mathrm{HL}-60$ cells expressing a bcl-2 cDNA transgene (Bcl-2:HL60 cells) have been described. ${ }^{42,43}$ The cells were cultured in RPM 1640 medium supplemented with $10 \%$ FBS, $1 \mathrm{mM}$ non-essential amino acids, $1 \mathrm{mM}$ sodium pyruvate, $100 \mathrm{U} / \mathrm{ml}$ penicillin and $50 \mathrm{U} / \mathrm{ml}$ streptomycin. Cells were incubated at $37^{\circ} \mathrm{C}$ in a humidified incubator with $5 \% \mathrm{CO}_{2}$

\section{Cell proliferation}

Cells $\left(0.5-1 \times 10^{6}\right)$ were seeded in $5 \mathrm{ml}$ of medium in $60-\mathrm{mm}$ dishes in the presence or absence of various concentrations of the compounds tested. The total cell number per dish was then determined in triplicate every $24 \mathrm{~h}$.

\section{Determination of apoptosis by DAPI staining, analysis of DNA, and protein degradation}

Cells were washed in PBS once and fixed in a $2 \%$ paraformaldehyde$0.1 \%$ Triton X-100 PBS solution for $30 \mathrm{~min}$ at $4^{\circ} \mathrm{C}$. The cells were then washed in PBS once and stained with $100 \mathrm{ng} / \mathrm{ml}$ DAPI in PBS for $10 \mathrm{~min}$ at room temperature. An aliquot of the stained cells was then observed under a fluorescent microscope. Apoptotic cells were identified as those with densely stained granular nuclear bodies. ${ }^{60}$ For the analysis of DNA degradation, fragmented DNA was isolated from cells and analyzed by agarose electrophoresis. ${ }^{61,62}$ For the analysis of protein degradation, whole cell extract was prepared, and aliquots were subjected to electrophoresis and Western blot analyses for caspase-catalyzed cleavage of proteins. ${ }^{60,63}$

\section{Isolation of cytosolic S-100 extract and detection of mitochondrial cytochrome $c$ efflux, caspase-3 activation}

HL-60 cells were either left untreated or were treated with various compounds. The cells were then washed with PBS and cytosolic S-100 extracts were prepared. ${ }^{60}$ The protein concentration in the S-100 extract was determined and then adjusted to $10 \mu \mathrm{g}$ protein $/ \mathrm{mL}$ plus $50 \mathrm{mM} \mathrm{KCl}$, $5 \%$ glycerol and then stored in small aliquots at $-80^{\circ} \mathrm{C}$. To assay for the presence of cytochrome $c$ and the status of caspases, $S-100$ aliquots of $10 \mu \mathrm{L}$ were subjected to SDS - PAGE and Western blot analyses. ${ }^{60}$

\section{Detection of PKC-induced phosphorylation of c-Raf-1}

Preliminary investigation showed that the pretreatment of HL-60 cells with Bis-I, Bis-II, Bis-III, or Ro-31-8220, but not Bis-V, caused a dosedependent inhibition of PKC-catalyzed phosphorylation of Raf-1 when the cells were stimulated by phorbol-12-myristate acetate (PMA), a potent and specific PKC activator. Maximal inhibition of PMA-induced Raf-1 phosphorylation by the Bis analogs occurred between 7.5$10 \mu \mathrm{M}$ (data not shown). Therefore, for all subsequent studies, we utilized the Bis analogs at a concentration of $10 \mu \mathrm{M}$. HL-60 cells were either left untreated or treated with $10 \mu \mathrm{M}$ of each of the Bis analogs for $60 \mathrm{~min}$ and then the cells were stimulated with $100 \mathrm{nM}$ PMA for $30 \mathrm{~min}$. The cells were washed three times in PBS, pelleted by centrifugation, and then resuspended in three volumes of buffer $B$ (10 mM HEPES, pH 7.5, 2 mM EDTA, $50 \mathrm{mM} \beta$-glycerophosphate, $5 \mathrm{mM}$ sodium orthovanadate, $10 \mathrm{nM}$ okadaic acid, $2 \mathrm{mM} \mathrm{MgCl}_{2}, 1 \mathrm{mM}$ DTT, $1 \mathrm{mM}$ PMSF, $0.3 \%$ Triton X-100 and $10 \mathrm{mg} / \mathrm{ml}$ each of antipain, aprotinin, and leupeptin), and incubated on ice for $5 \mathrm{~min}$. The cells were broken by passing them five times through a 26-gauge needle fitted to a syringe, and the lysate was centrifuged at $12000 \times g$ for $10 \mathrm{~min}$ at $4^{\circ} \mathrm{C}$. The supernatant was further centrifuged at $100000 \times \mathrm{g}$ for $30 \mathrm{~min}$ at $4^{\circ} \mathrm{C}$. The protein concentration of the clarified supernatant was determined, adjusted to $4 \mu \mathrm{g} / \mu \mathrm{L}$ and then small aliquots were stored at $-80^{\circ} \mathrm{C}$. An aliquot of $40 \mu \mathrm{g}$ of S-100 extract from each sample was subjected to Western blot analyses to determine the phosphorylation status of c-Raf-1.

\section{General phosphorylation of proteins in HL-60 cells}

HL-60 cells were cultured in serum-free medium at a density of $3.5 \times 10^{6} \mathrm{cell} \mathrm{s} / \mathrm{ml}$ for $48 \mathrm{~h}$ with a medium change at the $24 \mathrm{~h}$ interval. $\left.{ }^{32} \mathrm{P}\right]$-Phosphoric acid was added to the culture medium $(71 \mu \mathrm{Ci} / \mathrm{ml}$ of cell culture), and the cells were incubated for another $3.5 \mathrm{~h}$ to allow the cells to accumulate an adequate pool of [ $\left.{ }^{32} \mathrm{P}\right]$ ATP. The cells were then washed three times with serum-free medium and approximately $1.5 \times 10^{7}$ cells were cultured in $9 \mathrm{ml}$ of serum-free medium containing either no drug or $10 \mu \mathrm{M}$ Bis-I, Bis-II, Bis-III, Bis-IV, or Ro-31-8220. The cells were then incubated for $60 \mathrm{~min}$ after which time each culture received $1 \mathrm{~mL}$ of fetal bovine serum and then the incubation was continued for an additional $10 \mathrm{~min}$. The cells were then pelleted by centrifugation, washed in serum-free medium once, and pelleted by centrifugation again. The cell pellet was lysed in $100 \mu \mathrm{L}$ of lysis buffer (10 mM HEPES, pH 7.5, $5 \mathrm{mM}$ EDTA, $5 \mathrm{mM}$ EGTA, $10 \mathrm{mM} \mathrm{NaF}$, $10 \mathrm{mM}$ sodium orthovanadate, $100 \mathrm{nM}$ okadaic acid, $1 \mathrm{mM}$ PMSF, $1 \mathrm{mM}$ DTT, $0.5 \%$ Triton $\mathrm{X}-100$ and $50 \mu \mathrm{g} / \mathrm{mL}$ each of antipain, aprotinin, and leupeptin). The lysate was incubated on ice for $5 \mathrm{~min}$, and centrifuged at $12500 \times \mathrm{g}$ for $10 \mathrm{~min}$. The supernatant was combined with $30 \mu \mathrm{L}$ of $4 \times$-SDS-loading buffer ( $40 \%$ glycerol, $4 \%$ SDS, $20 \% \beta$-mercaptoethanol, and $0.001 \%$ brilliant blue) and heated at $100^{\circ} \mathrm{C}$ for $5 \mathrm{~min}$. Aliquots of $20 \mu \mathrm{L}$ were then subjected to electrophoresis in $10 \%$ polyacrylamide gels and autoradiographic analyses.

\section{Acknowledgments}

This work was supported in part by a National Science Foundation grant MCB-9630362 (to JH Wyche and EA Hendrickson), and a Milheim Foundation for Cancer Research grant 99-10 (to Z Han). 


\section{References}

1. Vaux D and Korsmeyer SJ (1999) Cell death in development. Cell 96:245-254

2. Cory S (1998) Cell death throes. Proc. Natl. Acad. Sci. USA 95: 12077-12079

3. Green D (1998) Apoptotic pathways: the roads to ruin. Cell 94: 695-698

4. Raff M (1998) Cell suicide for beginners. Nature 396: 119-122

5. Alnemri ES, Livingston DJ, Nicholson DW, Salvesen G, Thornberry NA, Wong WW and Yuan J (1996) Human ICE/CED-3 protease nomenclature. Cell 87: 171

6. Cryns V and Yuan J (1998) Proteases to die for. Genes Dev. 12: 1551-1570

7. Thornberry NA and Lazebnik Y (1998) Caspases: enemies within. Science 281: $1312-1316$

8. Porter AG, Ng P and Janicke R (1997) Death substrates come alive. BioEssays 19: $501-507$

9. Green DR and Reed JC (1998) Mitochondria and apoptosis. Science 281:13091312

10. Reed JC (1997) Double identity for proteins of the Bcl-2 family. Nature 387: 773 776

11. Grant S, Turner AJ, Bartimole TM, Nelms PA, Joe VC and Jarvis WD (1994) Modulation of 1-beta-D-[arabinofuranosyl] cytosine-induced apoptosis in human myeloid leukemia cells by staurosporine and other pharmacological inhibitors of protein kinase c. Oncol. Res. 6: 87-99

12. Jarvis WD, Turner AJ, Povirk LF, Traylor RS and Grant S (1994) Induction of apoptotic DNA fragmentation and cell death in $\mathrm{HL}-60$ human promyelocytic leukemia cells by pharmacological inhibitors of protein kinase C. Cancer Res. 54: 1707-1714

13. Zhang W, Lawa RE, Hintona DR, Su Y and Couldwell WT (1995) Growth inhibition and apoptosis induction in human neuroblastoma SK-N-SH cells induced by hypericin, a potent inhibitor of protein kinase c. Cancer Lett. 96: 31 35

14. Hamilton HB, Hinton DR, Law RE, Gopalakrishna R, Su YZ, Chen ZH, Weiss MH and Couldwell WT (1996) Inhibition of cellular growth and induction of apoptosis in pituitary adenoma cell lines by the protein kinase c inhibitor hypericin: potential therapeutic application. J. Neurosurg. 85: 329-334

15. Kobayashi D, Watanabe N, Yamaguchi N, Tsuji N, Safo T, Sasaki H, Okamoto T and Niitsu Y (1997) Protein kinase $c$ inhibitors augment tumor-necrosis factorinduced apoptosis in normal human diploid cells. Chemother. 43: 415-423

16. Murray NR and Fields AP (1997) Atypical protein kinase $c$ iota protects human leukemia cells against drug-induced apoptosis. J. Biol. Chem. 272: 2752127524

17. Wang S, Urana JA, Bartimole TM, Freemerman AJ, Jarvis WD, Kramer LB, Krystal G, Dent P and Grant S (1997) Agents that down-regulate or inhibit protein kinase $\mathrm{c}$ circumvent resistance to 1 -beta-D-arabinofuranosylcytosine-induced apoptosis in human leukemia cells that overexpress bcl-2. Mol. Pharmacol. 52: $1000-1009$

18. Whitman SP, Civoli F and Daniel LW (1997) Protein kinase c beta ll activation by 1-beta-D-arabinofuranosylcytosine is antagonistic to stimulation of apoptosis and bcl-2 alpha down regulation. J. Biol. Chem. 272: 23481-23484

19. Caponigro F, French RC and Kaye SB (1997) Protein kinase c: a worthwhile target for anticancer drugs? Anticancer Drugs 8: 26-33

20. Datta R, Kojima H, Yoshida K and Kufe D (1997) Caspase-3-mediated cleavage of protein kinase $C$ d in induction of apoptosis. J. Biol. Chem. 272: 20317-20320

21. Ruvolo PP, Deng X, Carr BK and May WS (1998) A functional role for mitochondrial protein kinase $\mathrm{Ca}$ in $\mathrm{Bcl} 2$ phosphorylation and suppression of apoptosis. J. Biol. Chem. 273: 25436-25442

22. Ruegg UT and Burgess GM (1989) Staurosporine, K-252 and UCN-01: potent but nonspecific inhibitors of protein kinases. Trends Pharmacol. Sci. 7:541-546

23. Omura S, Sasaki Y, Iwai Y and Takeshima H (1995) Staurosporine, a potentially important gift from a microorganism. J. Antibiotic. 48: 535-548

24. Harkin ST, Cohen GM and Gescher A (1998) Modulation of apoptosis in rat thymocytes by analogs of staurosporine: lack of direct association with inhibition of protein kinase C. Mol. Pharmacol. 54: 663-670

25. Villalba M (1998) Bisindolylmaleimide prevents cerebellar granule cell apoptosis: a possible role for PKC. Neuroreport 9: 1713-1717

26. Nishizuka $Y$ (1995) Protein kinase $C$ and lipid signaling for sustained cellular responses. FASEB J. 9: 484-496

27. Reyland ME, Anderson SM, Matassa AA, Barzen KA and Quissell DO (1999) Protein kinase $C \delta$ is essential for etoposide-induced apoptosis in salivary gland acinar cells. J. Biol. Chem. 274: 19115-19123
28. Zhao X, Geschwend JE, Powell CT, Foster RG, Day KC and Day ML (1997) Retinoblastoma protein-dependent growth signal conflict and caspase activity are required for protein kinase $\mathrm{C}$-signaled apoptosis of prostate epithelial cells. J. Biol. Chem. 272: 22751-22757

29. Shao RG, Cao CX and Pommier Y (1997) Activation of PKC alpha downstream from caspases during apoptosis induced by 7-hydroxystaurosporine or the topoisomerase inhibitors, camptothecin and etoposide in human myeloid leukemia HL-60 cells. J. Biol. Chem. 272: 31321-31325

30. Denning MF, Wang Y, Nickoloff BJ and Wrone-Smith T (1998) Protein kinase C $\delta$ is activated by caspase-dependent proteolysis during ultraviolet radiationinduced apoptosis of human keratinocytes. J. Biol. Chem. 273: 29995-30002

31. Toullec D, Pianetti P, Coste H, Bellevergue P, Grand-Perret T, Ajakane M, Baudet V, Boissin P, Boursier E, Loriolle F, Duhamel L, Charon D and Kirilovsky $J$ (1991) The bisindolylmaleimide GF 109203X is a potent and selective inhibitor of protein kinase C. J. Biol. Chem. 266: 15771-15781

32. Davis PD, Hill CH, Lawton G, Nixon JS, Wilkinson SE, Hurst SA, Keech E and Turner SE (1992a) Inhibitors of protein kinasec. 1.2,3-bisarylmaleimides. J. Med Chem. 35: $177-184$

33. Davis PD, Elliott LH, Harris W, Hill CH, Hurst SA, Keech E, Kumar MKH, Lawton G, Nixon JS and Wilkinson SE (1992b) Inhibitors of protein kinase c. 2. Substituted bisindolylmaleimides with improved potency and selectivity. J. Med. Chem. 35: $994-1001$

34. Martiny-Baron G, Kazanietz MG, Mischak H, Blumberg PM, Kochs G, Hug H, Marme D and Schaechtele C (1993) Selective inhibition of protein kinase C isozymes by the indolocarbazole Go 6976. J. Biol. Chem. 268: 9194-9197

35. Wilkinson SE, Parker PJ and Nixon JS (1993) Isoenzyme specificity of bisindolylmaleimides, selective inhibitors of protein kinase C. Biochem. J. 294: 335-337

36. Birchall AM, Bishop J, Bradshaw D, Cline A, Coffey J, Elliott LH, Gibson VM, Greenham A, Hallam TJ, Harris W, Hill CH, Hutchings A, Lamont AG, Lawton G, Lewis EJ, Maw A, Nixon JS, Pole J, Wadsworth J and Wilkinson SE (1994) Ro-320432, a selective and orally active inhibitor of protein kinase $c$ prevents T-cell activation. J. Pharmacol. Exp. Therap. 268: 922-929

37. Morrison DK and Cutler RE (1997) The complexity of Raf-1 regulation. Curr. Opin. Cell Biol. 9: 174-179

38. Earnshaw WC (1995) Nuclear changes in apoptosis. Curr. Opin. Cell Biol. 7: $337-343$

39. Hsu H-L and Yeh N-H (1996) Dynamic changes of NuMA during the cell cycle and possible appearance of a truncated form of NuMA during apoptosis. J. Cell Sci. 109: $277-288$

40. Wyllie AH, Morris RG, Smith AL and Dunlop D (1984) Chromatin cleavage in apoptosis: association with condensed chromatin morphology and dependence on macromolecular synthesis. J. Pathol. 142: 67-77

41. El-Deiry WS (1997) Role of oncogenes in resistance and killing by cancer therapeutic agents. Curr. Opin. Oncol. 9: 79-87

42. Ibrado AM, Huang Y, Fang G, Liu L and Bhalla K (1996) Overexpression of Bcl-2 or Bcl-XL inhibits Ara-C-induced CPP32/Yama protease activity and apoptosis of human acute myelogenous leukemia HL-60 cells. Cancer Res. 56: 47434748

43. Han Z, Bhalla K, Pantazis P, Hendrickson EA and Wyche JH (1999) Cif (cytochrome cefflux-inducing factor) activity is regulated by $\mathrm{Bcl}-2$ and caspases and correlates with the activation of Bid. Mol. Cell. Biol. 19: 1381-1389

44. Sellins KS and Cohen JJ (1987) Gene induction by $\gamma$-irradiation leads to DNA fragmentation in lymphoctes. J. Immunol. 139: 3199-3206

45. Lowe SW, Schmitt EM, Smith SW, Osborne BA and Jacks T (1993) p53 is required for radiation-induced apoptosis in mouse thymocytes. Nature 362 : 847-849

46. Collins MKL, Marvel J, Malde P and Lopez-Rivas A (1992) Interleukin 3 protects murine bone marrow cells from apoptosis induced DNA damaging agents. J. Exp. Med. 176: 1043-1051

47. Bertrand R, Solary E, O'Connor P, Kohn KW and Pommier Y (1994) Induction of a common pathway of apoptosis by staurosporine. Exp. Cell Res. 211: 314-321

48. Han Z, Chatterjee D, Early J, Pantazis P, Hendrickson EA and Wyche JH (1996) Isolation and characterization of an apoptosis-resistant mutant of human leukemia $\mathrm{HL}-60$ cells that has switched expression from $\mathrm{Bcl}-2$ to $\mathrm{Bcl}-\mathrm{X}$. Cancer Res. 56: $1621-1628$ 
49. Rovera G, O'Brien TG and Diamond L (1979) Induction of differentiation in human promyelocytic leukemia cells by tumor promoters. Science 204: 868870

50. Wang Q, Worland PJ, ClarkJL, Carlson BA and Sausville EA (1995) Apoptosis in 7-hydroxystaurosporine-treated $T$ lymphoblasts correlates with activation of cyclin-dependent kinases 1 and 2. Cell Growth Differ. 6: 927-936

51. Westwick JK, Bielawska AE, Dbaibo G, Hannun YA and Brenner DA (1995) Ceramide activates the stress-activated protein kinases. J. Biol. Chem. 270: 22689-22692

52. Brenner B, Koppenhoefer $U$, Weinstock C, Linderkamp O, Lang F and Gulbins $E$ (1997) Fas- or ceramide-induced apoptosis is mediated by a Rac1-regulated activation of Jun N-terminal kinase/p38 kinases and Gadd153. J. Biol. Chem. 272: 22173-22181

53. ParkJ, Kim I, Oh YJ, Lee K-W, Han P-L and Choi EJ (1997) Activation of C-Jun Nterminal kinase antagonizes an anti-apoptotic action of Bcl-2. J. Biol. Chem. 272: $16725-16728$

54. Guo Y-L, Baysal K, Kang B, Yang L-Y and Williamson JR (1998) Correlation between sustained $\mathrm{c}$-Jun $\mathrm{N}$-terminal protein kinase activation and apoptosis induced by tumor necrosis factor-a in rat mesangial cells. J. Biol. Chem. 273 4027-4034

55. Meriin AB, Gabai VL, Yaglom J, Shifrin VI and Sherman MY (1998) Proteosome inhibitors activate stress kinases and induce Hsp72: diverse effects on apoptosis. J. Biol. Chem. 273: 6373-6379

56. Wang T-H, Wang H-S, Ichijo H, Giannakakou P, Foster JS, Fojo T and Wimalasena J (1998) Microtubule-interfering agents activate c-Jun N-terminal kinase/stress-activated protein kinases through both Ras and apoptosis signalregulated kinase pathways. J. Biol. Chem. 273: 4928-4936
57. Beltman J, McCormick F and Cook SJ (1996) The selective protein kinase C inhibitor Ro-31-8220, inhibits mitogen-activated protein kinase phosphatase-1 (MKP-1) expression, induces c-Jun expression, and activates Jun $\mathrm{N}$-terminal kinase. J. Biol. Chem. 271: 27018-27024

58. Shen L and Glazer RI (1998) Induction of apoptosis in glioblastoma cells by inhibition of protein kinase $\mathrm{C}$ and its association with the rapid accumulation of p53 and induction of the insulin-like growth factor-1-binding protein-3. Biochem. Pharmacol. 55: $1711-1719$

59. Wolf $D$ and Rotter $V$ (1985) Major deletions in the gene encoding the $p 53$ tumor antigen cause lack of p53 expression in HL-60 cells. Proc. Natl. Acad. Sci. USA 82: $790-794$

60. Han Z, Li G, Bremner TA, Lange TS, Zhang G, Jemmerson R, Wyche JH and Hendrickson EA (1998) A cytosolic factor is required for mitochondrial cytochrome $c$ efflux during apoptosis. Cell Death Differ. 5: 469-479

61. Han Z and Wyche JH (1994) Guanosine induces necrosis of cultured aortic endothelial cells. Amer. J. Pathol. 145: 423-427

62. Han Z, Chatterjee D, He DM, Early J, Pantazis P, Wyche JH and Hendrickson EA (1995) Evidence for a G2-checkpoint in p53-independent apoptosis induction by X-irradiation. Mol. Cell. Biol. 15: 5849-5857

63. Han Z, Carter TH, Reeves WH, Wyche JH and Hendrickson EA (1996) DNAdependent protein kinase is a target of a CPP32-like apoptotic protease. J. Biol. Chem. 271: $25035-25040$ 